\title{
Berrak Hücreli Renal Hücreli Karsinomda Fuhrman Derecesinin Tekrarlanabilirliğinin ve Prognostik Kullanımının Değerlendirilmesi
}

\author{
${ }^{1}$ Ata Özen, ${ }^{2}$ Emine Dündar Kasapoğlu, ${ }^{2}$ Mustafa Fuat Açıkalın, ${ }^{3}$ Cavit Can \\ ${ }^{1}$ Van Bölge Eğitim Araştırma Hastanesi, Üroloji A.D,Van. \\ ${ }^{2}$ Osmangazi Üniversitesi Tıp Fakültesi Patoloji A.D, Eskişehir \\ ${ }^{3}$ Osmangazi Üniversitesi Tıp Fakültesi Üroloji A.D, Eskişehir \\ e-posta: ata.ozen@hotmail.com
}

ÖZET: Çalışmamızın amacı, Fuhrman derecelendirme sistemindeki gözlemciler arası farklılı̆̆ ve tekrarlanabilirliği değerlendirmek ve Fuhrman derecelendirme sisteminin basitleştirilmiş kullanımında dikkat edilmesi gereken dereceleri saptamaktır. Metod: Kliniğimizde 1995 ile 2012 yılları arasında renal hücreli karsinom (RHK) tanısı alan hastalar çalışmaya dahil edildi. Hastaların sağkalım bilgileri dosyalardan ve hastalara telefonla ulaşllarak öğrenildi. Fuhrman dereceleri Grup A (Fuhrman 1 ve 2 ) ve Grup B (Fuhrman 3 ve 4) olmak üzere ikiye ayrıldı. Patoloji preparatlar ikinci patolog tarafindan yeniden değerlendirildi. Veriler, ilk değerlendirme, ikinci değerlendirme ve gruplandıktan sonra SPSS programında Kaplan Meier yöntemiyle analiz edildi. Çalışma için Eskişehir Osmangazi Üniversitesi etik kurulundan 2011 yllında izin alınmıştır (2011/243). Bulgular: İstatistiksel analiz, toplam 164 hastadan patoloji sonucu berrak hücreli RHK olarak rapor edilen 127 hastaya yapıldı. Hastalardan 70'i (\%55.1) erkek, 57'si kadın idi. Ortalama takip süresi 46.8 (Min-Max: 1-169, Median: 37) ay olarak hesaplandı. Olguların ilk değerlendirme, ikinci değerlendirme ve gruplama sonrasında yapılan sağkalım analizinde anlamlı istatistiksel fark saptandı $(\mathrm{p}<0.001)$. İkinci değerlendirme sonrası toplam 37 hastanın $(\% 29.1)$ derecesinde değişiklik saptandı. En çok Grade 2 ve 3 arasında değişiklik mevcuttu. Sonuç: Fuhrman derecesinin prognostik önemi orjinal şekliyle ya da gruplanarak değerlendirilirken özellikle sağkalımı birbirinden çok farklı olan Grade 2 ve 3 tümörlerin doğru şekilde ayırt edilmesine dikkat edilmelidir.

ANAHTAR KELIMELER: Renal hücreli karsinom, Berrak hücreli, Fuhrman derecesi, Sağkalım

SUMMARY: Objective: The aim of our study is to evaluate the interobserver aggrement and reproducibility of Fuhrman grading system and determine the Grades which is to be considered in using of simplified versions of Fuhrman Grading system. Methods: Between 1995-2012, patients who were diagnosed as renal cell carcinoma pathologically were included. Patients survival data was accessed by either from their file or reaching out to patients by phone. Fuhrman grades were divided into Group A (Fuhrman 1 and 2) and Group B (Fuhrman 3 and 4). Pathology slides were re-evaluated by another pathologist. Data were analyzed after the first assesment, second assesment and grouping by SPSS Kaplan Meier analysis. This study was approved by Eskişehir Osmangazi University ethics committee on 2011 (2011/243). Results: 127 of the total 164 patients who were diagnosed as clear cell renal cell carcinoma were statistically analyzed. Male and female patients were 70 (\%55.1) and $57(\% 44.9)$ respectively. Mean follow up was 46.8 (Min-Max: 1169, Median: 37) months. Significant differences were found after the first evaluation, second evaluation and grouping in survival analysis $(\mathrm{p}<0.001)$. Fuhrman grading changes were observed in 37(\%29.1) patients after the second evaluation. Most alteration was seen between grade 2 and 3.Conclusion: When Fuhrman Grade's prognostic significance is assessed either by its original form or grouped, Grade 2 and 3 tumours which survival rates are different from each other need a accurate way to distinguish.

KEY WORDS: Renal cell carcinoma, Clear cell, Fuhrman Grade, Survival 


\section{Giriş}

Renal Hücreli Karsinom (RHK) erişkinlerdeki tüm malign tümörlerin \%23'ünü oluşturmaktadır (1). Böbrek içinde en sık gelişen kitlesel lezyon olan RHK, belirli histopatolojik ve genetik özellikleri olan değişik alt tiplerden oluşur (2). Bu tümörler konvansiyonel kemoterapiye yanit vermez ve genitoüriner kanserler içinde en ölümcül seyredenidir (3). Bugüne dek RHK seyrinin tahmininde hastaya ait semptom ve bulgular, tümörle ilgili faktörler ve laboratuar verilerini kapsayan pek çok prognostik faktör ele alınmıştır. Bunlar arasında patolojik evre, tümör çap1, nükleer derece ve histolojik alt tip gibi tümöre bağlı faktörler en önemlileridir (4-6). Renal hücreli karsinomun derecelendirilmesinde, nükleer büyüklük ve yap1 ile nükleolus belirginliğini temel alan çeşitli sistemler önerilmiştir. $\mathrm{Bu}$ sistemlerin çoğu prognostik önem taşımasına rağmen tekrarlanabilir olmayışları ve gözlemciler arasındaki farklılıklar sorun yaratmıştır. Derecelendirme sistemlerinden en çok kabul gören ve tümör evresinden bağımsız olarak prognostik önem gösteren Fuhrman'in derecelendirme sistemidir (7). Çalışmamızın amacı, Fuhrman sistemindeki gözlemciler arası farklılığı ve tekrarlanabilirliği değerlendirmek ve Fuhrman derecelendirme sisteminin basitleştirilmiş kullanımında dikkat edilmesi gereken dereceleri saptamaktır.

\section{Gereç ve Yöntemler}

Bu çalışmada Kasım 1995 ile Ocak 2012 tarihleri arasında Eskişehir Osmangazi Üniversitesi T1p Fakültesi Üroloji Anabilim Dalı'nda böbrek tümörü nedeniyle radikal nefrektomi veya nefron koruyucu cerrahi yapılan ve patoloji sonucu RHK olarak rapor edilen 164 hastanın klinik ve demografik verileri incelendi. Hastalara ait klinik, laboratuvar ve patolojik parametreler hasta dosyalarından temin edildi. Düşük evre ve derecedeki hastaların, daha uzun aralıklarla, genellikle iki yönlü akciğer grafisi ve batın ultrasonografisi ile, gerektiğinde ve şüphe durumunda abdominopelvik ve toraks bilgisayarlı tomografi (BT) ile takip edildiği, yüksek evre ve derecedeki hastaların ise iki yönlü akciğer grafisi veya toraks ve abdominopelvik BT incelemesi ile daha s1k aralıklarla takip edildiği tespit edildi. Ayrica takiplerde hastalara böbrek fonksiyon testleri ve karaciğer fonksiyon testlerinin çalışıldığ 1 belirlendi. Hastalara metastaz taramasında rutin kemik sintigrafisi ve beyin BT çekilmediği, bu incelemelerin şüphe durumunda veya semptomatik hastalarda tercih edildiği görüldü. Hastaların takiplerindeki fizik muayene, laboratuvar bulguları ve radyolojik görüntülemeleri ile son durumlar1 dosya bilgilerinden, "ENLİL hastane bilgi sisteminden" ve telefonla hastalara ulaşılarak öğrenildi. Dosyalarına, patoloji raporlarına ulaşılamayan ya da telefonla görüşülemeyen takipsiz hastalar ile berrak hücreli karsinom dışındaki alt tipler çalışma dışında bırakıldı. Patolojik inceleme sonucu berrak hücreli renal hücreli karsinom tanısı alan hastaların patoloji spesmenleri ürolojik patoloji konusunda deneyimli bir patolog tarafından tekrar incelenerek tümör tipi ve derecesi yeniden belirlendi. Evreleme için TNM 2010 evreleme sistemi kullanılırken nükleer derecelendirme için Fuhrman grade sistemi kullanıldı. Bu çalışma için 22.11.2011 tarihinde Eskişehir Osmangazi Üniversitesi T1p Fakültesi Etik Kurul Başkanlığı'ndan 2011/243 sayılı kararı ile izin alındı.

\section{İstatistiksel Analiz}

$\mathrm{Bu}$ çalışmada sürekli değişkenler ortalama \pm standart sapma (ss) olarak gösterildi. Kategorik değişkenler frekans ve yüzde şeklinde gösterildi. Yaşam analizi olarak Kaplan Meier yöntemi kullanıldı 
İstatistiksel önemlilik için $p<0.05$ değeri kabul edildi. İstatistiksel analizler için IBM SPSS Statistics 15.0 (SPSS Inc., Chicago, Illinois) programı kullanıldı.

\section{Bulgular}

Takiplerine, patoloji preparatlarına ulaşılabilen ve renal hücreli karsinom olarak rapor edilen 164 hastadan 37'si berrak hücreli karsinom olmadığı için çalışma dışında bırakıldı. İstatistiksel analizler 127 hasta üzerinden yapıldı. Hastalardan 70'i (\%55.1) erkek, 57'si (\%44.9) kadın olup ortalama yaşları 56.5 yıl (yaş aralığ 1 26-80) idi. Ortalama takip süresi 46.8 (Min-Max: 1-169, Median: 37) ay olarak hesaplandı. Takip sırasinda tümör nedenli ölen hasta sayısı 22 (\%17.3) idi. Tümörlerin ilk ve yeniden değerlendirmeleri sonucunda elde edilen histolojik derecelerinin dağılımı Tablo 1 ve 2'de verilmiştir.

Tablo 1.

Tümörlerin ilk değerlendirmedeki histolojik derecelerinin dă̆ılımı

\begin{tabular}{ccc}
\hline Fuhrman Derecesi & $\mathbf{n}$ & \% \\
\hline 1 & 14 & 11.0 \\
2 & 66 & 52.0 \\
3 & 32 & 25.2 \\
4 & 15 & 11.8 \\
\hline Toplam & $\mathbf{1 2 7}$ & $\mathbf{1 0 0}$ \\
\hline
\end{tabular}

Tablo 2.

Tümörlerin yeniden değerlendirmedeki histolojik derecelerinin dağılımı

\begin{tabular}{ccc}
\hline $\begin{array}{l}\text { Fuhrman Derecesi } \\
\text { (Yeniden değerlendirme sonrası) }\end{array}$ & $\begin{array}{c}\text { Hasta } \\
\text { Sayısı }\end{array}$ & \% değerleri \\
\hline 1 & 16 & 12.6 \\
2 & 56 & 44.1 \\
3 & 40 & 31.5 \\
4 & 15 & 11.8 \\
\hline Toplam & $\mathbf{1 2 7}$ & $\mathbf{1 0 0}$ \\
\hline
\end{tabular}

Yeniden değerlendirme sonucunda, ilk değerlendirmede Grade 1 hastalardan 5'i Grade 2, 1'i Grade 3, Grade 2 hastalardan 13'ü Grade 3, 8'i Grade 1, Grade 3 hastalardan 6's1 Grade 2, 2'si Grade 4, Grade 4 hastalardan ise 2'si Grade 3 olarak derecelendirildi. Çalışma kapsamındaki 127 hastanın yeniden değerlendirilmesinde Grade 1 hasta sayısının 14'ten (\%11) 16'ya (\%12.6) çıktığı, Grade 2 hasta sayısının 66'dan (\%52) 56’ya (\%44.1) düştüğü, Grade 3 hasta sayısinın 32'den (\%25.2) 40'a (\%31.5) çıktığı, Grade 4 hasta sayısının ise 15 (\%11.8) olduğu ve değişmediği görüldü. Toplam 37 hastanın (\%29.1) derecesinde değişiklik saptandı. Ondokuz hasta ile en çok Grade 2 ve 3 arasında değişiklik mevcuttu. Olguların ilk değerlendirmesine göre yapılan sağkalım 
analizi Resim 1'de görülmekte olup dereceler arasında anlamlı istatistiksel fark mevcuttu $(\mathrm{p}<0.001)$ ve buna göre beş yıllık sağkalım oranları Fuhrman Grade 1, 2,3 ve 4 için sirasıyla $\% 91, \% 88, \% 50$ ve $\% 15$ olarak bulundu. Yeniden değerlendirilme sonrası yapılan sağkalım analizinde ise bu oranlar sirasiyla \%100, $\% 85, \% 63$ ve $\% 15$ olarak saptand 1 $(\mathrm{p}<0.001) \quad($ Resim 2).Yeniden değerlendirme öncesi Grade 1 ve 2 ile
Grade 3 ve 4'ün sağkalım eğrilerinin yakın olduğu görüldü ve hastalar Grup A (Fuhrman 1 ve 2) ve Grup B (Fuhrman 3 ve 4) olarak iki gruba ayrılarak sağkalım analizi yeniden yapıldığında yine iki grup arasında anlamlı farklılık olduğu görüldü $(\mathrm{p}<0.001) \quad($ Resim 3). Gruplama yapıldığında Grup A ve Grup B için 5 yıllık sağkalım oranları sirasıyla $\% 90$ ve $\% 52$ olarak bulundu.

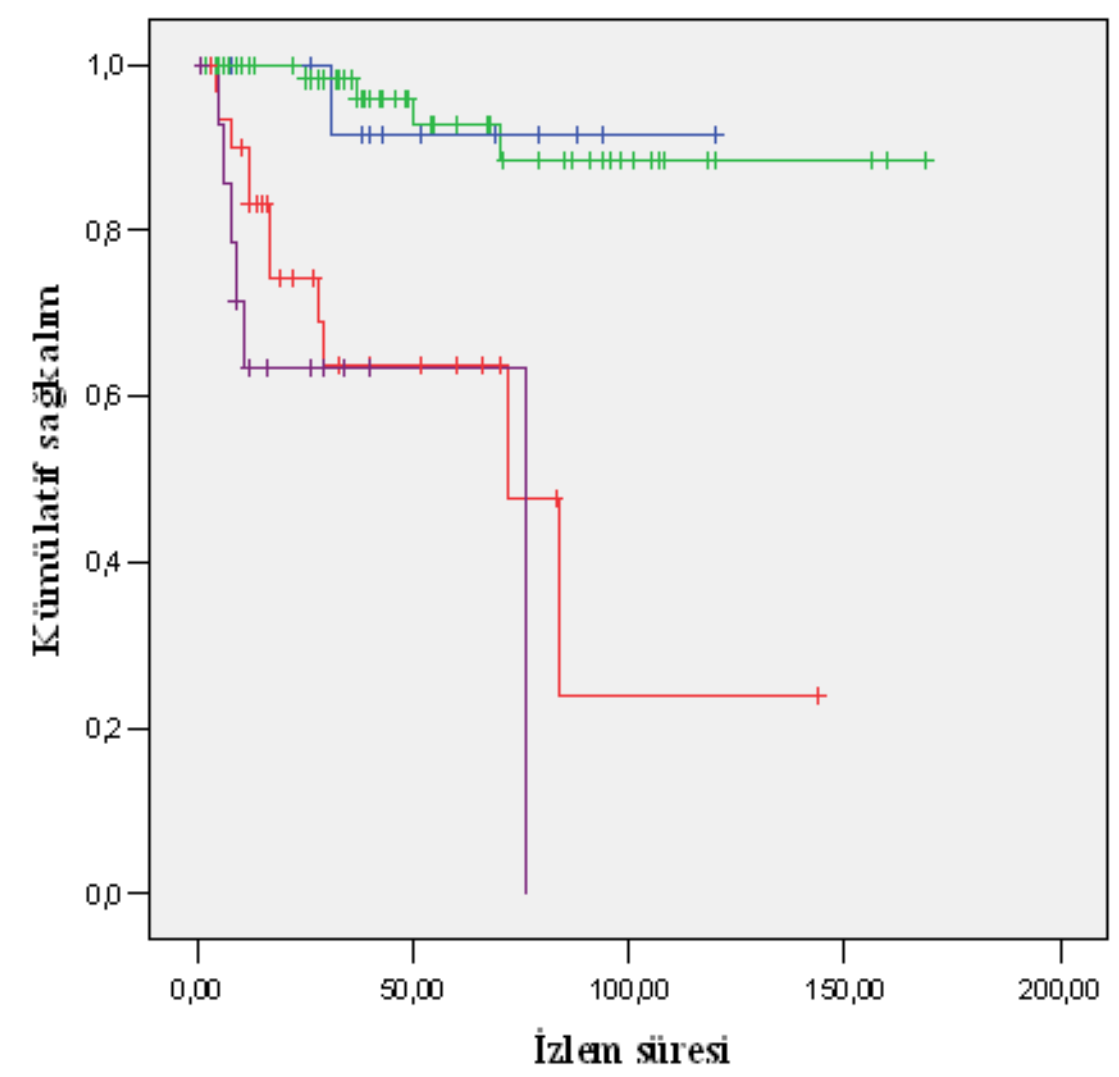

Fuhrman der ecesi

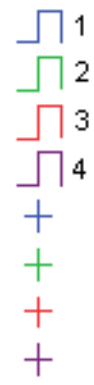

Resim 1. İlk dĕgerlendirme sonuçlarına göre histolojik derece ve să̆kalım ilişkisi 


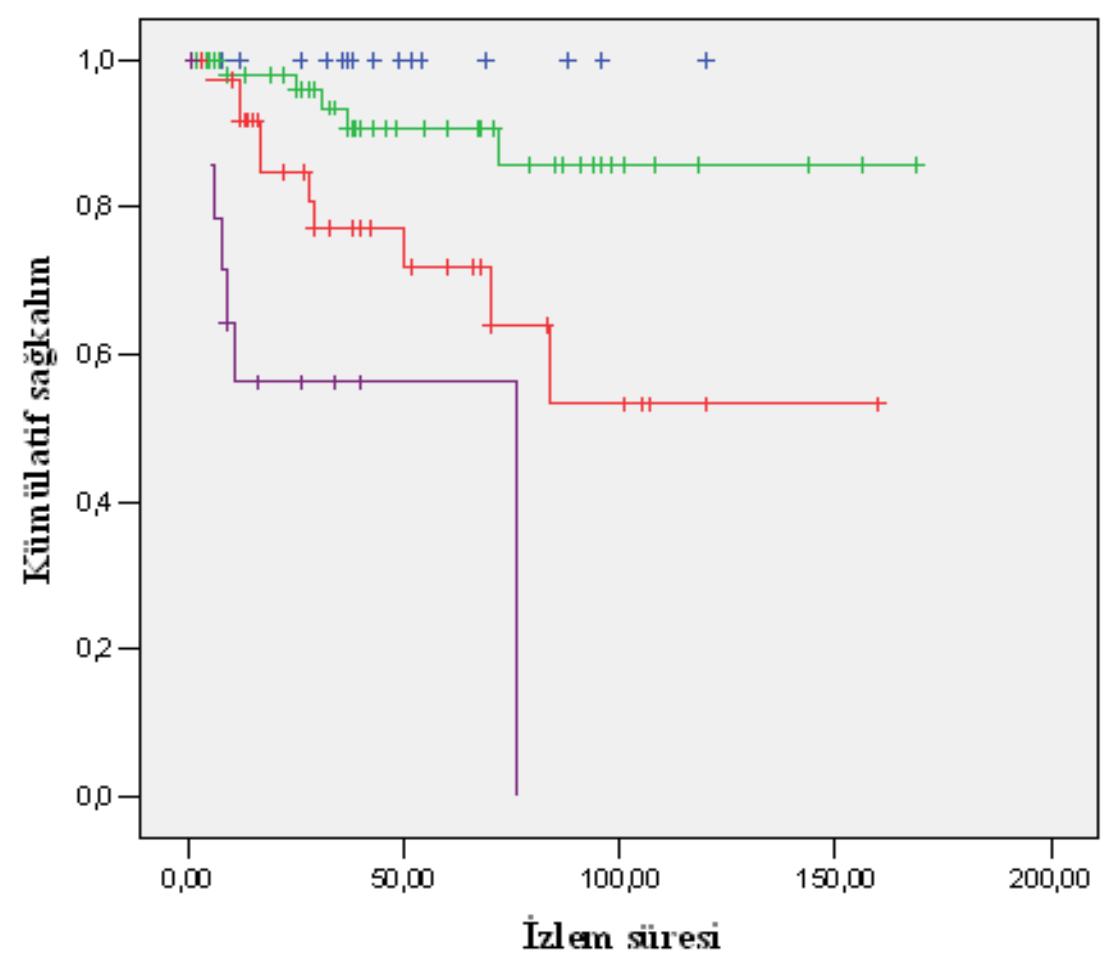

Yeniden değerlendirilen Fuhrman derecesi $\sqcap 1$
$\square 2$
$\sqcap 3$
$\sqcap 4$
+
+
+
+

Resim 2. Yeniden değerlendirme sonuçlarına göre histolojik derece ve să̆kalım ilişkisi

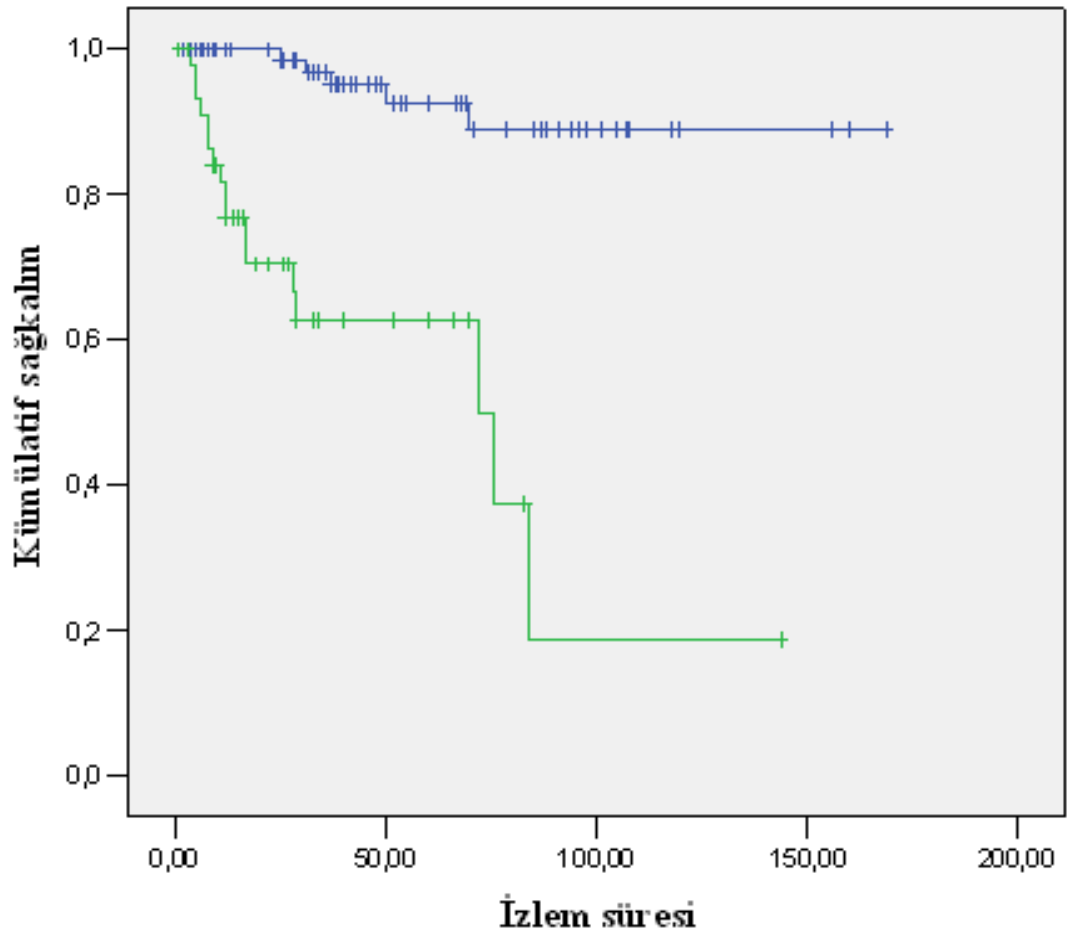

Fuhrman der ecesi iki grup

$\Pi$ Gup A

$\sqcap$ Grup B

$+$

$+$

Resim 3. Fuhrman derecesi Grup A (Fuhrman 1 ve 2) ve Grup B (Fuhrman 3 ve 4)

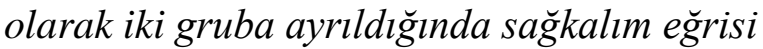




\section{Tartışma}

Renal hücreli karsinomda radikal nefrektomi sonrası tedavi planı ve takip için sağkalımı öngörebilmek oldukça önemlidir. Evre, tümör boyutu, histolojik derece ve histolojik tip gibi pek çok faktör sağkalım açısından önemlidir. Tümörlerin histolojik derecelendirmesi için y1llar içinde çok sayıda derecelendirme sistemi önerilmiştir. $\mathrm{Bu}$ sistemlerin çoğu tekrarlanabilir olmayışları ve gözlemciler arasındaki farklılıklar nedeniyle sorun yaratmıştır. Renal hücreli karsinomlarda derecelendirme sistemleri arasında en çok kabul gören ve bugün için halen kullanılan, Fuhrman ve arkadaşları tarafindan 1982 yılında tanımlanan derecelendirme sistemidir (7). $\mathrm{Bu}$ derecelendirme sistemine göre Grade 1 tümörlerde nükleus küçük (yaklaşık 10 $\mu \mathrm{m})$, yuvarlak ve uniform, nükleolus belirsizdir. Grade 2 tümörler daha büyük (yaklaşık $15 \mu \mathrm{m}$ ) ve düzensiz sinırlı nükleusa sahip, nükleolusları ancak büyük büyütmede (x400 büyütme) görülebilen hücrelerden oluşan tümörlerdir. Grade 3 tümörler belirgin düzensiz sinırlı, iri nükleusa sahip (yaklaşık $20 \mu \mathrm{m}$ ), nekleolusları x100 büyütmede görülebilenhücrelerden oluşur. Grade 4 tümörleri Grade 3'ten ayıran özellik ise bizar, multilobüle nükleus ve kaba kromatin kümeleridir (7). Çeşitli çalışmalarda 5 yıllık sağkalım çok farklı oranlarda bildirilmektedir ve Grade 1 için \%50-97, Grade 2 için \%30-90, Grade 3 için \%10-78, Grade 4 için \%9-66 olarak oldukça farkl1lık göstermektedir (8-10). Çalışmamızda iki kez değerlendirilen hastalarda sağkalım Grade 1 için \% 91100, Grade 2 için \%88-85, Grade 3 için $\% 50-63$ ve 4 için \%15-15 olarak bulunmuştur. Yeniden değerlendirme sonras1 özellikle Grade 3 hastaların sağkalım oranının \%50'den \%63'e yükseldiği görülmüştür. Bunun nedeninin yeniden değerlendirme sonrası Grade 3 hastalardan 6'sının Grade 2'ye düşmesine karşıl1k, Grade 2 hastalardan 13'ünün Grade 3'e yükselmesinden kaynaklanabileceği düşünülmüştür. Fuhrman derecelendirme sisteminin prediktif değer taşıdığ1 birçok çalışmada gösterilmekle birlikte bazı çalışmalarda bu sistemin sadece derece gruplaması ardından prediktif öneme sahip olduğu ortaya konmuştur. Çok merkezli ve 5453 hastayla yapılan bir çalışmada Fuhrman derecesi iki şekilde gruplanarak öngörü değeri araştırılmıştır. İlk gruplamada 3 gruba ayrılarak grade 1 ve 2 birleştirilmiş, ikincide ise Grade 1 ve 2 ile Grade 3 ve 4 birleştirilerek iki grup oluşturulmuştur. $\mathrm{Bu}$ gruplamaların tek değişkenli ve çok değişkenli analizlerle öngörü değeri hesaplanmıştır. Hem tek değişkenli hem de çok değişkenli analiz sonucunda her iki gruplamanın da bağımsız bir prognostik değere sahip olduğu bulunmuştur (10). Çalışmadaki hastaların \%71.4'ü Fuhrman Grade 2 ve 3 olup hastaların patoloji preparatları yeniden değerlendirmeye tabi tutulmamıştır. Bizim yaptığımız analizde en fazla karışıklığın Grade 2 ve 3 arasında olduğu saptanmıştır. Çalışmadaki hastaların yaklaşık 3/4’ünün Grade 2 veya 3 olduğu ve yapılan gruplama çalışmalarında bu iki derecenin ayrı gruplarda yer aldığ düşünüldüğünde gruplamanın belki de preparatların ikinci kez değerlendirildikten sonra yapılmasının daha uygun olabileceği kanaatindeyiz. Fuhrman nükleer derecesinin değerlendirildiği prognostik çalışmalarda farklı renal hücreli karsinom tiplerinin çalışmaya dahil edilmesi de sağkalım analizlerinde yanlışlıklara yol açabilmektedir. Birçok araştırmacı Fuhrman nükleer derecesinin prognostik değerinin sadece berrak hücreli ve papiller renal hücreli karsinom için geçerli olduğunu vurgulamaktadır (11). Çalışmalarda berrak hücreli karsinomun papiller ve kromofob renal hücreli karsinoma göre daha kötü prognoza sahip olduğu gösterilmiştir (12). Geniş serilerle yapılan çalışmalarda tek bir tümör subtipinin çalışmaya dahil edilmesi daha uygun olacaktır. Ficarra ve arkadaşlarının 
yapmış olduğu ve sadece berrak hücreli karsinom olgularını içeren çalışmada preparatlar yeniden tek bir patolog tarafindan incelendiğinde Fuhrman nükleer derecesi ile sağkalım arasındaki uyum sinirda anlamlı $\quad(p=0.44)$ bulunmuştur (8). Yeniden incelemede en çok değişiklik Grade 1 ve 2 olgularda izlenirken Grade 3 ve 4 olgularda herhangi bir farklılık bulunmamıştır. Bunun üzerine araştırmacılar Grade 1 ve 2'nin gruplanarak 3 basamaklı derecelendirme kullanılabilecegini önermişlerdir. Bizim çalışmamızda, olgularda ilk ve yeniden değerlendirme sonucunda en çok değişimin Grade 2 ve 3 arasında olduğu saptanmıştır.Lang ve arkadaşlarının 241 hastayı dahil ettikleri ve değerlendirmenin üç farklı patolog tarafindan yapıldı ğ çalışmada sadece 58 hastada (\%24) patologların Fuhrman derecesi hakkında aynı fikirde olduğu bulunmuştur. En iyi uyumun Grade 1 ve 2 ile Grade 3 ve 4 gruplandığında ortaya çıktığ1 görülmüş ve iki basamaklı derecelendirme sistemi önerilmiştir (13). Genel olarak, berrak hücreli RHK'larda Fuhrman nükleer derecesi ile sağkalım arasında iyi bir korelasyon mevcut olmakla birlikte, Fuhrman sisteminde patologların nükleer boyutu ölçmesi gerekmektedir. Ayrica Grade 2 ve Grade 3 tümörleri ayırdetmek için nükleolusun x100 ve x400 büyütmede belirgin olup olmaması kullanılmaktadır, ancak bu noktada gözlemciler arası farklılık oldukça belirgindir (14). Çalışmamızda Fuhrman derecesi ilk değerlendirme sonucunda, yeniden değerlendirildiğinde ve Grup A (Fuhrman 1 ve 2) ve Grup B (Fuhrman 3 ve 4) şeklinde iki gruba ayrılarak değerlendirildiğinde prognostik değer taşıdığı görülmüştür. İlk değerlendirme sonucunda iki gruba ayırmamızın sebebi Grade 1 ve 2 ile 3 ve 4'ün sağkalım eğrilerinin birbirine yakın seyretmesi idi. Ancak ikincil değerlendirme sonucunda derecesi değişen 37 hastadan 19'unun (\%51.4) Grade 2 ve 3 tümörler olduğu görüldü. Fuhrman derecesi gruplanarak değerlendirildiğinde prognostik değeri değişmese de özellikle Grade 2 ve 3 tümörlerin değerlendirilmesinde ve bir gruba dahil edilirken daha dikkatli olunması gerekmektedir. Çünkü yapılan çalışmaların birçoğunda Grade 2 ve 3 tümörler farklı gruplarda değerlendirilmektedir. Özellikle Grade 2 ve 3 tümörlerdeki derecelendirme farklılıkları ve bu iki hasta grubunun ciddi sağkalım farkı hastaların takibinde ve sağkalımının değerlendirilmesinde zorluklara yol açmaktadır. Gruplama sistemlerinin de bu sorunu çözme konusunda katkısı sınırlı görünmektedir ve klinik kullanımda bugün için tercih edilmemektedir. $\mathrm{Bu}$ nedenle, farklı klinik seyir gösteren bu iki derecedeki olguların daha dikkatli değerlendirilmesi ve gerekirse derece verilmeden önce ürolojik patoloji konusunda deneyimli ikinci bir patolog tarafından da değerlendirilip karar verilmesinin uygun olacağı görüşündeyiz. Ayrica derecelendirme sistemlerindeki kriterlerin gözlemciler arası farklılığı en aza indirgeyecek ve tekrarlanabilirliği yüksek olacak şekilde daha objektif hale getirilmesinin de sorunun çözümünde anahtar role sahip olduğunu düşünmekteyiz. $\mathrm{Bu}$ konuda yapılacak prospektif daha geniş olgu serilerine ihtiyaç duyulmaktadır. 


\section{KAYNAKLAR}

1. Landis, S.H. Murray, T. Bolden, S. Wingo, P.A. (1999) Cancer statistics 1999. CA Cancer J Clin, 49, 8-31.

2. Kovacs, G. Akhtar, M. Beckwith, B.J. Bugert, P. Cooper, C.S. (1997). The Heidelberg classification of renal cell tumors. J Pathol, 83,131-133.

3. Yagoda, A. Abi-Rached, B. Petrylak, D. (1995) Chemotherapy for advanced renal-cell carcinoma: 1983-1993. Semin Oncol. 22(1), 42-60.

4. Kattan, M.W. Reuter, V. Motzer, R. J. Katz, J. Russo, P .(2001). A postoperative prognostic nomogram for renal cell carcinoma. J Urol, 166, 63-67.

5. Zisman, A. Pantuck, A.J. Dorey, F. Said, J.W. Shvarts, O. Quintana, D. Gitlitz, B.J. deKernion, J.B. Figlin, R.A. Belldegrun, A.S. (2001). Improved prognostication of renal cell carcinoma using an integrated staging system. J Clin Oncol, 19,1649-57.

6. Frank, I. Blute, M.L. Cheville, J.C. Lohse, C.M. Weaver, A. L. Zincke, H. (2002). An outcome prediction model for patients with clear cell renal cell carcinoma treated with radical nephrectomy based on tumor stage, size, grade and necrosis: the SSIGN score. J Urol, 168, 2395-2400.

7. Fuhrman, S.A. Lasky, L.C. Limas, C. (1982). Prognostic significance of morphologic parameters in renal cell carcinoma. Am J Surg Pathol, 6(7), 655-63.

8. Ficarra, V. Prayer-Galetti, T. Novella, G. Bratti, E. Maffei, N. Dal Bianco, M. Artibani, W. Pagano, F. (2003). Incidental detection beyond pathological factors as prognostic predictor of renal cell carcinoma. Eur Urol, 43, 663-9.
9. Patard, J.J. Leray, E. Rioux-Leclercq, N. (2005). Prognostic value of histologic subtypes in renal cell carcinoma: a multicenter experience. $J$ Clin Oncol, 23, 2763-71.

10. Rioux-Leclercq, N. Karakiewicz, P.I. Trinh, Q.D. Ficarra, V. Cindolo, L. de la Taille, A. Tostain, J. Zigenuer, R. Mejean, A. Patard, J.J. (2007). Prognostic ability of simplified nuclear grading of renal cell carcinoma. Cancer, 109, 868-74.

11. Medeiros, L.J. Jones, E.C. Aizawa, S.A. Aldepe, H.C. Cheville, J.C. Goldstein, N.S. Lubensky, I.A. Ro, J. Shanks, J. Pacelli, A. Jung, S.H. (1997). Grading of renal cell carcinoma: Workgroup No. 2. Cancer, 80, 990-991.

12. Cheville, J.C. Lohse, C.M. Zincke, H. Weaver, A.L. Blute, M.L. (2003) Comparison of outcome and prognostic features among histologic subtypes of renal cell carcinoma. Am J Surg Pathol, 27, 612-624.

13. Lang, H. Lindner, V. de Fromont, M. Molinie, V. Letourneux, H. Meyer, N. Martin, M. Jacqmin, D. (2005). Multicenter determination of optimal interobserver agreement using the Fuhrman grading system for renal cell carcinoma: assessment of 241 patients with >15-year follow-up. Cancer, 103, 625-629.

14. Lanigan, D. Conroy, R. Barry-Walsh, C. Loftus, B. Royston, D. Leader, M. (1994). A comparative analysis of grading systems in renal adenocarcinoma. Histopathology, 24, 473-476. 